Људмила В. ПОПОВИЋ * Универзитет у Београду Филолошки факултет
Оригинални научни рад Примљен: 21. 11. 2017. Прихваћен: 27. 12. 2017.

\title{
О УЗАЈАМНОМ УТИЦАЈУ КАТЕГОРИЈА ДИЈАТЕЗЕ И МОДАЛНОСТИ У СРПСКОМ ЈЕЗИКУ НА ПРИМЕРУ ГЛАГОЛА ТРЕБАТИ*
}

\footnotetext{
У оквиру категорија дијатезе и модалности разматра се питање узајамног утицаја глаголских категорија. Утицај доминантног значења модалности на рецесивно значење дијатезе посматра се на примеру тзв. потенцијалног и прескриптивног пасива, када модалност одређује редукцију пасивне парадигме до облика 3. лица презента имперфективних глагола. Поставља се питање о утицају дијатезе на модалност. Разматра се случај специфичне функционалне дијатезе у конструкцијама са нецеситивно употребљеним глаголом требати. У конструкцијама функционалног пасива са глаголом требати запажа се ширење парадигме глагола до свих личних облика уз потискивање рецесивне модалности, што сведочи о могућности не само редуковања парадигме елемента рецесивне категорије, већ и њеног ширења.

Кључне речи: дијатеза, модалност, доминатна категорија, рецесивна грамема, глагол требати.

Тренировка грамматического зрения у лексикографа и лексикографического у грамматиста открывает новые перспективы для лингвистики в целом. Очень вероятно, что на этом пути нас ждут новые открытия (Апресјан 2013: 79).
}

Питање узајамног утицаја глаголских категорија, као и граматичких категорија уопште, спада у најактуелнија и најмање истражена у савременој лингвистици (Плунгјан 2011; Маљчуков 2011; Маљчуков/Храковски 2015; Храковски 2015). Тај проблем се може сагледати и са тачке гледишта одговарајућих хијерархијских односа, када се постојање грамеме подређене

\footnotetext{
*1judmila.popovic@fil.bg.ac.rs

** Рад је настао у оквиру пројекта 178021 „Опис и стандардизација српског језика”, који финансира Министарство науке, просвете и технолошког развоја Републике Србије.
} 
категорије посматра као детерминисано присуством одређене грамеме код надређене категорије. На узајамну зависност глаголских категорија и њихову хијерархијску условљеност у руском језику скренута је пажња у радовима В. С. Храковског (Храковски 1996, 2012, 2015), у којима се на грађи руског језика истиче сврсисходност анализе глаголских грамема у комплексу са њиховим актантима, тј. у оквиру конструкције која чини језгро исказа приликом његовог генерисања. На тај начин даје се предност граматици конструкције у односу на вербоцентрични приступ опису реченице и самог глагола (Храковски 2015: 778).

Циљ овог рада се састоји у експликацији хијерахијске зависности међу глаголским грамемама у српском језику, која би омогућила уочавање утицаја доминантне категорије на подређену у смислу блокирања рецесивног граматичког значења, односно евентуалног супротног процеса - утицаја доминантне категорије у смислу ширења, а не сужавања другог значења, што ће бити приказано на примеру утицаја категорије пасива на категорију модалности.

Као пример утицаја доминантног значења модалности на рецесивно значење дијатезе може се узети употреба тзв. потенцијалног и прескриптивног пасива, уп.:

(1) Bрата се отварају: PRS.IPFV овим кључем. = Bрата се могу отворити, ако Х употреби овај кључ.

(2) Bрата су се отворила: PRF.PFV.PASS. = Х је отворио врата.

(3) Суnа се кува: PRS.IPFV на тихој ватри. = Супу треба кувати на тихој ватри.

(4) Cynа ће се кувати: FUT I. IPFV.PASS на тихој ватри. $=$ X ће кувати супу на тихој ватри.

У примерима (1) и (3) пасивни облици глагола отварати и кувати употребљени су у модалним конструкцијама, што потврђује њихова трансформација у реченице активне дијатезе, у којима им одговарају искази са модалним глаголима моћи и требати. Модалност у овом случају одређује редукцију пасивне парадигме до облика 3. лица презента имперфективних глагола јер употреба перфективног глагола или другог видско-временског облика лишава конструкцију модалног значења, о чему сведоче примери (2) и (4).

Развој модалних значења код пасивних глаголских облика, првенствено оних који се односе на могућност и немогућност обављања радње на објекту, истраживачи сматрају последицом померања пажње са извршиоца радње на њен резултат. Као пример таквог модалног значења, пре свега, наводе поменути потенцијални пасив (Плунгјан 2011). Конструкције са потенцијалним пасивом се одликују блокирањем агентивне допуне, први семантички актант у њима се не попуњава (Врата се откључавају специјалним кључем). Такве конструкције могу бити тумачене као пасивне (Пажњ, врата се затварају [возач изговара фразу у тренутку када притиска на дугме]), али и као медијалне - са недефинисаним агенсом (Врата се закључавају [у питању је инхерентно обележје самог предмета]).

Прескриптивни пасив (Савкова 2014: 107-108) представља посебан случај утицаја модалности на пасивну дијатезу у српском језику. Српским 
примерима са прескриптивним пасивом у другим словенским језицима могу одговарати конструкције активне дијатезе, уп.

(5) На часу се не прича. - (рус.) Во время урока не разговаривают.

Поставља се питање да ли доминантно значење пасива може потиснути рецесивну модалност. Као подстицај за размишљање у том правцу послужио нам је српски глагол требати. У речнику српског језика налазимо следеће тумачење тог глагола:

требати, -а(м) несвр. 1. безл. потребно је, нужно је, ваља. - Треба да даш дете $у$ школу. 2. (с логичким субјектом у дативу) имати потребу за чим. - Треба ми новаи (РСЈ 2011: 1308).

О глаголу требати у српском језику постоје бројни радови, а воде се и честе дискусије о његовој исправној употреби ${ }^{1}$, том глаголу су посвећени шири описи у оквиру граматика српског језика, као и монографија посвећених истраживању категорије модалности (Марковић 1950, 1980; Стевановић 1967; 1974: 603-604; Мразовић/Вукадиновић 1990: 148; Ђукановић 1994; Остојић 1997; Трбојевић Милошевић 2004: 163-164; Танасић 1995-96; Звекић Душановић 2011: 160-162; Кликовац 2011, 2016; Пипер/Клајн 2013: 164-166). Међутим, у свим наведеним истраживањима претежно се разматра питање деонтичке употребе глагола требати уз профилисање проблема нормативности његових личних облика, док се друго значење само констатује јер се лична употреба требати у том значењу не доводи у питање.

Полазећи од Апресјанове концепције интегралног описа лексеме у оквиру системске лексикографије која подразумева да се јединици лексикографског описа приступа са тачке гледишта исказа, а не саме глаголске лексеме (Апресјан 1995), уочавамо да су наведена значења условљена валентношћу глагола требати у предикату. У првом случају посреди је тзв. тривијална употреба ${ }^{2}$ ове лексеме, која се јавља када уз њу стоји реченична допуна у облику конструкције $\partial a+$ презент или инфинитива, ређе номинализације, док се у другом случају на позицији актанта овог глагола јавља предметни аргумент: Треба ми новац. Нетривијалност у овом случају настаје као последица изостављања унутрашњег предиката у функцији допуне глагола требаmи. Враћање елидираног глагола укида тривијалност: Треба да имам новац; Треба да ми даш новачз

${ }^{1}$ Само на страницама часописа Наш језик, како наводи Срето Танасић, о том питању се у више наврата дискутовало од 30-их година 20. века до данас (в. Танасић 2005: 51)

${ }^{2}$ Тривијално или адитивно значење исказа је такво које се добија слагањем лексичких елемената у целину уз помоћ одређених семантичких и синтаксичких правила. Оно настаје као последица слагања редундантних ЛСВ (Апресјан 1995). Нетривијално или неадитивно значење је пак оно које настаје као последица утицаја одређених активних чинилаца контекста на садржај исказа, те се његов смисао не може декодирати полазећи само од лексикографског тумачења лексеме. У улози таквих активних чинилаца могу наступати како лексички показатељи (квантори, евалуатори, модалне речи), тако и граматички - врста допуне, негација, вид и сл.

${ }^{3}$ На потребу систематског проучавања глагола који се повезују са различитим семантичко-синтаксичким типовима допуне скренула је пажњу Милка Ивић (Ивић 1995: 129). У цитираном раду, на примеру српског глагола имати, показано је како глагол мења своје лексичко значење у зависности од објекта с којим се спаја: имам пса = „власник сам пса”, имам аутобус у 3 = „пос- 
У нетривијалном значењу глагол требати отвара нову синтаксичку позицију коју попуњава логички субјекат у дативу, што сведочи о промени валентне структуре глагола требати. Из претежно једновалентног (у безличној употреби) или двовалентног (када је лично употребљен у перфекту) и сентенцијално транзитивног (Ивић 1995: 128) он постаје двовалентан са предметним аргументима. Међутим, у корелацији са исказом Треба ми новач у српском језику налази се и ређе коришћен исказ са личним обликом глагола требати Требам новаи, где је глагол требати двовалентан и транзитиван - има праву предметну допуну.

Очигледно је да је у овом случају на категорију модалности утицала валентност, коју тумачимо као семантичко-синтаксичку категорију. Валентност одређује категорије персоналности и прелазности с аспекта отворености глаголске лексеме за леву или десну валентност. С обзиром на то да категорија прелазности утиче на категорију дијатезе (само прелазни глаголи могу исказивати пасивну дијатезу), а категорија персоналности условљава категорије лица, времена и начина (само лични глаголи могу имати наведена граматичка значења), валентност утиче на све релативне глаголске категорије.

На примеру глагола требати видимо како валентност може утицати и на категорију модалности јер постојање сентенцијалне допуне јесте основа за издвајање модалних глагола, а замена сентенцијалне допуне предметном води потискивању модалног значења, што ће бити показано у даљем излагању.

Нетривијално значење глагола требати - „имати потребу за чим”, које се у Нормативној граматици српског језика издваја као нецеситивно (Пипер/ Клајн 2013: 164), допушта ширење парадигме овог глагола на све лично-временске облике, као и укључивање у његову деривативну парадигму грамеме свршеног вида, уп.: требам ти, требаш ми, треба ми одмор, требамо својим родитељима, требате пријатељима, требају ми ичипеле; требао сам ти, требаћу ти увек; затребао ми је алат; затребаћеш ми у једном тренутку итд. ${ }^{4}$

Поставља се питање, ако се парадигма глагола изградила до пуне и укинута је блокада свих нереализованих грамема, шта се дешава са модалним значењем те речи? Пре него што одговоримо на то питање, приметићемо да се у свим наведеним примерима глагол требати (или његов свршени корелат затребати) користи у конструкцији која функционално подсећа на пасивну дијатезу. Уколико пођемо од чињенице да се у сваком од наведених примера на позицији субјекта налази тзв. нецеситивни објекат, односно предмет

тоји аутобус који полази у 3 , а којим се служим”, имам час у $3=$ „предстоји ми час у $3 ”$, имам да ћутим и трпим = „приморана сам да ћутим и трпим”. Примећујемо да се уз сентенцијалну допуну глагол имам користи у модалном значењу, које се потискује приликом употребе тог глагола са предметном допуном, слично као и у случају глагола требати.

${ }^{4} \mathrm{O}$ регуларности реченица Требам нове иипеле у Нормативној граматици српског језика речено је следеће: „Реченице типа Друштво треба стручњаке, мада ниуколико нису погрешне, мање су препоручљиве од реченица типа Друштву требају стручњации, којима претходне увек могу бити замењене, али нема разлога да се оне доследно избегавају или да се уместо реченица типа Друштво треба стручњаке увек употребљавају, такође исправне, реченице са изразом бити потребан у предикату, нпр. Друштву су потребни стручњащи. Употреба синонимичних конструкција у истом контексту понекад је оправдана из стилских разлога” (Пипер/Клајн 2013: 165). 
потребе, онда можемо такву конструкцију посматрати као неку врсту функционалног пасива. У том случају полазимо од синтаксичке основе дијатезе - објекат прелази на позицију граматичког субјекта, а логички субјекат се исказује допуном у дативу. У лингвистичкој литератури познато је издвајање тзв. лексичког пасива, тј. конструкција у којима долази до колизије граматичке форме глагола и њеног значења (Бондарко 2002: 604). Конструкције са лексичким пасивом обично подразумевају тематизацију логичког објекта који се из комуникативних разлога топикализује (Алановић 2009: 127), уп.:

(6) Овај злочин је предмет истраге федералне полииије.

(7) Федерална полиција истражује овај злочин.

Међутим, у српским конструкцијама са глаголом требати могућ је и други начин исказивања пасивне дијатезе, када долази до тематизације логичког објекта, а глаголски облик, притом, остаје у облику активне дијатезе, нпр.

(8) Ивану требају нове чипеле.

Том приликом, како сматрају истраживачи ${ }^{5}$, долази до потискивања модалног значења глагола требати. Такав пасив можемо назвати функционалним, а у његовој основи лежи поменута синтаксичка транспозиција, као и семантички однос конверзије, који чини основу сваке пасивне конструкције. Њему одговара обележена конструкција активне дијатезе са тематизованим логичким субјектом - носиоцем стања уз исти глаголски облик, као и уз очекивану промену лица и броја с обзиром на конгруенцију глаголског облика у предикату са именицом на позицији синтаксичког субјекта:

(9) Иван треба нове ципеле.

(10) И данас верујем у Бога, али не требам председника. (Политика 30. 11. 2009) ${ }^{6}$

(11) Јоч једну опрему требамо за наше путовање, бело хаиијско одело. (М. Миланковић)

При преласку предметне допуне на позицију синтаксичког субјекта, што се може у функционалној равни изједначити са испољавањем пасивног значења, његова обличка парадигма се шири. Глагол требати у значењу „бити потребан” или „осећати потребу” срећемо у српском језику у свим личновременским облицима. Претражујући електронски корпус савременог српског језика, можемо наћи бројне примере са тим глаголом како уз нецеситивни објекат на позицији субјекта и логички субјекат у дативу тако и у примерима са нецеситивним објектом у акузативу, који су, међутим, ређи. Однос између та два типа конструкција зависи од личног облика глагола требати, али

\footnotetext{
${ }^{5}$ Ивана Трбојевић-Милошевић тим поводом примећује да у таквим конструкцијама глагол требати спада у медијалне глаголе јер изражава стање потребе за нечим, где се не може говорити о модалном значењу. „Ако би се баш инсистирало на његовој модалности и у тим случајевима, евентуално би се могло рећи да изражава буломаичку модалност, с обзиром да су жеља и потреба релативно блиска стања (жеља изазива потребу и обрнуто), мада бих рекла да би то било наметање модалности тамо где јој нема места" (Трбојевић Милошевић 2004: 162).

${ }^{6}$ Примери се наводе према извору: Корпус савременог српског језика на Математичком факултету Универзитета у Београду.
} 
тип налик функционалном пасиву (са нецеситивним објектом на позицији субјекта) убедљиво доминира.

Тако, за облик 1. л. једн. требам од укупно 29 примера 10 је са нещеситивним објектом на позицији субјекта (у даљем тексту I типа), а 7 са глаголом требати и нецеситивним објектом у акузативу (даље - II типа).

I тип: (12) Jа сам ту, па ако вам требам за добробит државе, позовите ме. (Svet 220).

II тип: (13) Требам доктора Комаровског. (Б. Пекић).

За облик 1.л.мн. требамо од укупно 65 примера 3 су првог типа, а 2 - другог.

I тип: (14) Унија треба нама, али је истина и то да ми требамо Унији. (Политика 18. 06. 2009)

II тип: (15) Требамо партнере да им продамо радне снаге. (Република 359)

Облик требаш нисмо успели да пронађемо у коришћеном корпусу, али се он често може чути у разговорном језику (II тип конструкције са обликом требаш је знатно ређи), о чему сведоче примери из разговорног дискурса или са интернета, нпр.:

І тип: (16) Ти ми требаш.

II тип: (17) Требаш нову опрему.

За облик 2. л. мн. требате у корпусу има 6 примера I типа конструкције и упола мање - II типа:

I тип: (18) Кажете да Вама не треба Мишковић, али можда Ви требате њему. (Политика 16. 01. 2008)

II тип: (19) Да, кога требате, није ту, јавите се сутра. (3. Вељић)

Примери са обликом 3. л. мн. требају у личној употреби су веома бројни. На 100 анализираних примера од укупно 587, колико их је пронађено претрагом корпуса, 69 је I типа, а 23 - II.

І тип: (20) Него мy требају гола факта! (М. Црњански)

(21) Машини требају радници и инжињери. (Б. Ћосић)

II тип: (22) Друже Чељустников, рече му непознати, требају вас хитно у Рајком. (Д. Киш)

(23) Све оне, дабогме, кажу да другог мушкариа, осим мужа, не требају. (М. Црњански)

Највише је пронађено примера са обликом 3. л. једн. - 111.865, што је логично јер се тај облик подудара са модалним безличним. Ипак међу њима има и значајан број примера са глаголом требати у личној употреби:

I тип: (24) Чим нешто затреба, знате где сам! Рекли сте да не треба ништа! Cећате се? А сада - треба! Значи да је требало! - Не

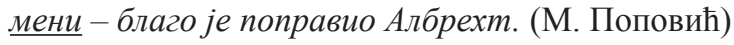

\footnotetext{
${ }^{7}$ Остали примери су заступљени конструкцијама са допунском реченицом (инфинитивом или допуном $\partial a+$ презент), које се не сматрају нормативним (Пипер/Клајн 2013: 164-166).
} 
У последњем примеру (24) налазимо глагол требати и у облику перфекта. Тај временски облик срећемо у личној употреби са нецеситивним објектом на позицији субјекта претежно у 3 . л. мн., и то у конструкцијама I типа:

(25) Новим агенцијама требали су нови ьуди, новим људима канцеларије и опрема, а све то захтевало је додатне паре. (Политика 20. 07. 2010)

Када је у питању указивање на прошли временски план, чешће се користи свршени видски парњак глагола требати - затребати, који се јавља у свим облицима презента: затребам-затребам-затреба-затребамо-затребате-затребају, претежно у зависном делу условне или временске реченице:

(26) Кад год ти што затребам, само пошаљи, јави (Б. Станковић).

(27) Да, да, нико нема разумевања за наме невоље, а кад им затребамо сви гракну. (Политика, 23. 09. 2007)

Префикс за- у овом случају маркер је како перфективности глагола тако и његовог почетно-фазног значења, што се, када је у питању изражавање нецеситивности, у осталим словенским језицима, осим српског, хрватског, бугарског и македонског, може пренети само контекстуално - употребом имперфективног глагола или предикатива који је од њега изведен уз лексичка средства, која модификују њихово значење у почетно (у чешком, словачком, лужичкосрпском) или помоћу фазног глагола стати у осталим језицима ${ }^{8}$, уп.:

(28) Затреба она пријатељима.

(29) (буг.) На нея й затрябваха/потрябваха нейните приятели.

(30) (л.-срп.) [Jednoho dnja] jeje přećeljo ju trjebachu.

(31) (чеш.) [A najednou] ji začali potřebovat!

(32) (слов.) Potrebovali ju jej priatelia.

(33) (укр.) Вона стала потрібна свойм друзям.

(34) (рус.) Она стала нужна своим друзьям.

У простим или напоредносложеним реченицама српског језика облик свршеног презента глагола затребати јавља се у хабитуалном значењу:

(35) Али стари смо, затребају нам лекови, а напада снег, не можемо до штале краве да видимо, а камо ли до Батрага и Тутина. (Политика 10. 11.2010)

У наведеном примеру глагол затребају значи „дешава се да нам требају”, што указује на тзв. итеративну хабитуалност.

Свршени глагол затребати може се јавити и у облику перфекта или аориста, али само у личном облику:

\footnotetext{
${ }^{8}$ Користим ову прилику да искажем своју искрену захвалност колегама-славистима, који су ми помогли да обухватим истраживањем примере на свим словенским језицима - Андреи Желе, Каролини Скварској, Стефани Пауновић Родић, Светли Русковој, Далибору Соколовићу и Микити Супрунчуку.
} 
(36) као она млада што је легла у гроб са свадбеним велом који јој за живота није затребао. (Д. Киш)

(37) И сачувах здравље, и снагу што бодри, и не затребах их, годинама 'вамо. (Web)

(38) Затребаме ми нама слова. (Web)

Свршени глагол затребати у облику перфекта или аориста не повезује на позицији допуне инфинитив или конструкцију $\partial a+$ презент, што сведочи о томе да се тај глагол среће само у значењу „бити потребан” и „осетити потребу".

Када посматрамо парадигму глагола требати у значењу „бити потребан” и „осећати/осетити потребу”, примећујемо да је она употпуњена не само свим личним облицима, већ и оним видско-временским облицима (перфективни перфект и аорист) који се не срећу у деонтичкој употреби. Очигледно је да је парадигма глагола требати у том значењу много шира него код његове деонтичке употребе. Остаје само да разјаснимо шта се дешава са модалним значењем како бисмо потврдили или оповргли почетну претпоставку да је до ширења парадигме дошло услед губитка потоњег.

У бројним истраживањима посвећеним категорији модалности на материјалу различитих језика издвајају се њихове заједничке функционалне карактеристике (Палмер 1986; Бондарко 1990; Бајби и др. 1994; Ван дер Аувера, Плунгјан 1998; Нарог 2005; Пипер 2005: 636-647), међу којима је основна та да изводе радњу означену предикатом ван граница реалности придајући јој нефактивно значење. Самим тим модални глаголи морају увек имати пропозицију чији садржај чине нефактивним приказујући га из угла односа између стварности и, са друге стране, говорника или субјекта реченице, радње и самог садржаја реченице. Уколико су показатељи модалности као појмовне категорије универзални, средства њеног изражавања и степен њихове граматикализације разликују се од језика до језика. У лексичка средства исказивања модалности спадају модални глаголи са одређеним морфосинтаксичким показатељима, који се такође разликују од језика до језика-

Настојећи да раздвоји модалне глаголе од осталих глагола у српском језику, Бјорн Хансен (Хансен 2005: 220) говори о њиховој полифункционалности, тј. способности модалних глагола да изражавају најмање два типа модалности, док модализоване речи, по његовом мишљењу, изражавају само једно. Говорећи о њиховим морфосинтаксичким одликама, истраживач инсистира на томе да модални глаголи у српском језику увек имају само једну аргументну позицију коју попуњава глаголска лексема, те немају своје номиналне аргументе али увек утичу на енкодирање аргумената пунозначне глаголске лексеме (Хансен 2007: 34).

Међутим, ако бисмо свели морфосинтаксичке показатеље модалности у српском језику на најосновније, добили бисмо следеће:

1) Модални глаголи су семикопулативни и имају уз себе на позицији допуне инфинитив или конструкцију $\partial a+$ презент: могу читати/д $a$ читам; треба сачекати; морам да идем итд. 
2) У већини немају аспектуални корелат без промене семантике глагола: моћи $\sim \mathrm{X} ;$ морати $\sim \mathrm{X}, x т е т и ~ \sim \mathrm{X}$ (са друге стране, постоје перфективни глаголи различите семантике у односу на модалне, од којих су изведени, в. смоћи, приморати, прохтети се итд.).

3) Немају облик императива: *Можси!, *Требай!, *Нека мора!

4) Од модалних глагола се ретко користе глаголске именице: хтети - хтење, требати-требање, морати - морање 9 , а од неких је немогуће формирати глаголску именицу, уп. моћи - *моћење, смети $-{ }^{*}$ смене).

5) Модални глаголи се срећу у реченицама које се могу трансформисати у конструкције пасивне дијатезе, али се притом дијатезној трансформацији подвргава тзв. пунозначни глагол:

(39) Он може да затвори прозор. - Прозор може бити затворен.

(40) Он треба да набави карте. - Карте треба да се набаве.

Када се глагол требати у значењу „бити потребан” и „осећати потребу" упореди са овим критеријумима, постаје јасно да, иако у њему постоји модална основа коју можемо означити као нецеситивну (Пипер/Клајн 2013: 164) или буломаичку (Трбојевић Милошевић 2004: 162), ипак такво значење пре можемо сматрати постмодалним (Бајби и др. 1994) јер је у њему дошло до потискивања општег модалног значења услед промене валентне структуpe, када је аргумент елидираног унутрашњег предиката прешао на позицију допуне услед сажимања предикатске допуне.

Што се тиче морфосинтаксичких одлика постмодалног глагола треба$m u$, оне се битно разликују од оних које су му својствене при деонтичкој употреби. Као прво, за разлику од деонтичког требати, постмодална варијанта тог глагола захтева предметну именицу на позицији аргумента, и то у акузативу или номинативу. Као друго, појављује се логички субјекат у дативу. И, најзад, постоји могућност да се свршени парњак овог глагола, који се користи у свим временским облицима, употреби у императивној или оптативној конструкцији, нпр.:

(41) Нека ти никад не затребају ови лекови.

(42) Желим да Вам никад не затребају туђе жеље (https://forum.krstarica.com).

Кад глагол требати улази у конструкцију пасивне дијатезе у свом деонтичком значењу, он попут других модалних глагола, не прима пасивни облик, већ само модификује значење пасивно употребљеног пунозначног глагола (39-40). Ако се ради о постмодалном глаголу требати, он може самостално исказати однос пасивне дијатезе уз померање нецеситивног објекта на позицију субјекта:

(43) Требам нове иипеле - Требају ми нове цииеле.

\footnotetext{
${ }^{9}$ У коришћеном корпусу нашли смо 2 примера употребе такве именице и то у дискурсу спортског коментара: Притом, јасно ми је да је у фудбалу морање опасно. (Политика 04. 02. 2001). Исте облике налазимо и у речнику. Очигледно је да се у случају глаголских именица ради о семантизацији модалних глагола.
} 
Конструкције са нецеситивним објектом на позицији субјекта су уобичајене, док су оне где он остаје на позицији синтаксичког објекта мање присутне у српском језику. Наведено говори у прилог томе да је до ширења парадигме глагола требати у српском језику дошло због његове употребе у конструкцијама са тематизованим објектом које се у функционалној равни могу посматрати као пасивне. Таква синтаксичка транспозиција је узроковала додатну семантизацију глагола требати, који је почетно био модалан. Речено нам даје основа да сматрамо да је дијатеза утицала на модалност тако што је дошло до ширења парадигме модалног глагола уз потискивање рецесивне модалне грамеме.

\section{ЛИТЕРАТУРА}

Алановић 2009: М. Алановић, Лексичко-синтаксичка средства пасивизаиије, Научни састанак слависта у Вукове дане, 38/1, 123-135.

Апресјан ${ }^{2}$ 1995: Ю. Д. Апресян, Избранные труды, том I. Лексическая семантика, Москва: Школа „Языки русской культуры”.

Апресјан 2013: Ю. Д. Апресян, Грамматика русского глагола в словаре, Јужнословенски филолог, LXIX, 49-73.

Бајби и др. 1994: J. Bybee, R. Perkins, W. Pagliuca, The Evolution of Grammar. Tense, aspect and modality in the languages of the world, Chicago and London: The University of Chicago Press.

Бондарко 1990: А. В. Бондарко (отв. ред.), Теория функииональной грамматики. Темпоральность. Модальность, Ленинград: Наука.

Бондарко 2002: А. В. Бондарко, Теория значения в системе функииональной грамматики. На материале русского языка, Москва: РАН, Институт лингвистических исследований.

Ван дер Аувера/Плунгјан 1998: J. Van der Auwera, V. A. Plungian, Modality's semantic map, Linguistic typology, 2, 79-124.

Ван Валин/Ла Пола 1997: R. D. Van Valin, R. J. La Polla, Syntax. Structure, meaning and function, Cambridge: CUP.

Ђукановић 1994: В. Ђукановић, Глаголи требати и ваљати и њихова инфинитивно/презентска допуна, Научни састанак слависта у Вукове дане, 22/2, Београд, 119-126.

Звекић Душановић 2011: D. Zvekić-Dušanović, Modalnost. Motivaciona modalnost u srpskom i mađarskom jeziku, Novi Sad: Filozofski fakultet.

Ивић ${ }^{2}$ 1995: M. Ivić, Lingvistički ogledi, Beograd: Slovograf [Biblioteka XX vek 61].

Кликовац 2011: Д. Кликовац, О глаголу требати: теорија, употреба и норма, Нам језик, XLII/3-4, 3-24.

Кликовац 2016: Д. Кликовац, Муке с глаголом ТРЕБАТИ, и даље, Језик данас, XII/7-8, 11-20.

Маљчуков 2011: A. L. Malchukov, Interaction of verbal categories: Resolution of infelicitous grammeme combinations, Linguistics 49/1, 229-282. 
Маљчуков/Храковски 2015: А. Л. Мальчуков, В. С. Храковский, Наклонение во взаимодействии с другими категориями: опыт типологического обзора, Вопросы языкознания, 6, 9-32.

Марковић 1950: С. Марковић, О употреби личних и безличних облика глагола требати, Наш језик, 1/7-8, 311-317.

Марковић 1980: С. Марковић, Лични и безлични облици глагола требати (посматрани из аспекта варијаната српскохрватског стандардног језика), Јужнословенски семинар за стране слависте, 31, Београд, 81-92.

Нарог 2005: H. Narrog, Modality, mood and change of modal meaning. A new perspective, Cognitive linguistics, 16/4, 677-731.

Палмер 22001: F. R. Palmer, Mood and Modality, Camridge: Cambridge University Press.

Пипер 2005: П. Пипер, Синтаксичке категорије у простој реченици (синтаксичка семантика), у: П. Пипер, И. Антонић, В. Ружић, С. Танасић, Љ. Поповић, Б. Тошовић, Синтакса савременог српског језика. Проста реченииа, М. Ивић (ред.), Београд: Институт за српски језик САНУ, Београдска књига - Нови Сад: Матица српска, 575-978.

Пипер/Клајн 2013: П. Пипер, И. Клајн. Нормативна граматика српског језика, Нови Сад: Матица српска.

Плунгјан 2011: В. А. Плунгян, Введение в грамматическую семантику: грамматические значения и грамматические системы языков мира, Москва: РГГУ.

Савкова 2014: Д. Савкова, Деагентивността в българския език и нейното изразяване (в съпоставка със сръбския език), София: Университетско издателство „Св. Климент Охридски”.

Стевановић 1967: М. Стевановић, Облици другог дела сложеног предиката код допуне безлично употребљеног глагола требати, Наш језик, XIV, 237-243.

Стевановић 1974: М. Стевановић, Савремени српскохрватски језик (граматички системи и књижевнојезичка норма II. Синтакса, Београд: Научна књига.

Танасић 1995-1996: С. Танасић, О употреби глагола требати, Наш језик, $\mathrm{XXX/1-5:} \mathrm{44-52.}$

Танасић 2005: С. Танасић, Синтаксичке теме, Београд: Београдска књига.

Трбојевић Милошевић 2004: I. Trbojević-Milošević, Modalnost, sud, iskaz. Epistemička modalnost u srpskom i engleskom jeziku, Beograd: Filološki fakultet.

Хансен 2005: B. Hansen, How to measure areal convergence: a case study of contact-induced grammaticalization in the German/Hungarian/Slavonic contact area, in: B. Hansen, P. Karlik (eds.), Modality in Slavonic languages. New perspectives, München: Verlag Otto Sagner, 219- 237.

Хансен 2007: B. Hansen, A morpho-syntactic typology of constructions with modals in Serbian, Синтаксичка истраживана (дијахроно-синхрони план). Лингвистичке свеске, 6, Нови Сад: Филозофски факултет, 31-43. 
Храковски 1996: В. С. Храковский, Грамматические категории глагола (опыт теории взаимодействия), в: Межкатегориальные связи в грамматике: Сб. статей под ред. А.В. Бондарко, СПб: Изд-во „Дмитрий Буланин”, $22-42$.

Храковски 2012: V. S. Khrakovskij, Hierarhy and Interaction of Russian Verb Categories (Aspect, Tense, Mood), Scando-Slavica, 58/1, 49-76.

Храковски 2015: В. С. Храковский, Русский глагол: иерархия грамматических категорий и их взаимодействие в пассивных конструкциях, у: Љ. Поповић, Д. Војводић, М. Номаћи (ур.), У простору лингвистичке славистике. Зборник радова поводом 65. година живота академика Предрага Пипера, Београд: Филолошки факултет, 777-798.

Людмила В. Попович

О ВЗАИМОДЕЙСТВИИ КАТЕГОРИЙ ДИАТЕЗЫ И МОДАЛЬНОСТИ В СЕРБСКОМ ЯЗЫКЕ НА ПРИМЕРЕ ГЛАГОЛА ТРЕБАТИ

Резюме

В работе рассматривается взаимодействие грамматических категорий в сербском языке. В частности, в рамках теоретической концепции В. С. Храковского о иерархическом взаимодействии категорий исследуется влияние доминантной категории модальности на рецессивную категорию пассива в случае так называемого потенциального и прескриптивного пассива. В таких конструкциях парадигма пассива сводится к единственной форме - 3. л. ед. ч. наст. вр. глаголов несов. вида.

Пример сербского глагола требати, который можно использовать как в модальном значении, так и для обозначения состояния потребности, показывает, что при употреблении данного глагола в последнем значении конструкции с ним вступают в конверсивные отношения, которые на синтаксическом уровне можно оценить как функциональную диатезу - объект потребности становится синтаксическим субъектом, а логический субъект переходит на позицию субъектного дополнения: требам доктора - треба ми доктор. Конструкции с функциональным пассивом (требати в значении „быть востребован”) являются более распространенными и рекомендуются с точки зрения культуры речи. В таком случае пассивная граммема является доминантной, а модальная рецессивной, поскольку модальное значение глагола требати, стандартно выражаемое безличной формой, вытесняется при восполнении парадигмы этого глагола всеми лично-временными формами в конструкциях функционального пассива. Данный факт свидетельствует о том, что результатом влияния доминантной категории на рецессивную может быть не только свертывание парадигмы элементов рецессивной категории, но и ее восполнение новыми формами.

Ключевые слова: диатеза, модальность, доминантная категория, рецессивная граммема, глагол требати. 